\title{
Transverse sacral fractures and concomitant late-diagnosed cauda equina syndrome
}

\author{
Şenol Bekmez, M.D., ${ }^{1}$ Gökhan Demirkıran, M.D., ${ }^{2}$ Ömür Çaglar, M.D., ${ }^{2}$ \\ İbrahim Akel, M.D., ${ }^{3}$ Emre Acaroğlu, M.D. ${ }^{4}$
}

${ }^{1}$ Department of Orthopedics and Traumatology, Dr. Sami Ulus Maternity, Child Health and Disease Training and Research Hospital, Ankara; ${ }^{2}$ Department of Orthopedics and Traumatology, Hacettepe University Faculty of Medicine, Ankara;

${ }^{3}$ Department of Orthopedics and Traumatology, İzmir Kent Hospital, İzmir;

${ }^{4}$ Department of Orthopedics and Traumatology, Ankara Spine Center, Ankara

\begin{abstract}
Transverse sacral fractures in young patients occur with high-energy mechanisms. Because of the drawbacks in radiographic and neurologic evaluations of the sacral area in polytrauma patients, misdiagnosis is quite common. In this study, we aimed to report our clinical results in three patients with displaced transverse sacral fractures compromising the sacral canal and concomitant late-diagnosed (at least 48 hours) cauda equina syndrome. Bilateral lumbopelvic fixation, followed by sacral laminectomy and decompression, was performed in all patients. Despite the late- diagnosed cauda equina syndrome, we observed that surgical decompression and lumbopelvic fixation had positive effects on neurologic recovery, pain relief and early unsupported mobilization.
\end{abstract}

Key words: Cauda; equina; misdiagnosed; sacral; transverse.

\section{INTRODUCTION}

Because of the difficulties in radiographic imaging and subtle clinical signs, sacral fractures are challenging injuries in traumatology. Vertically oriented sacral fractures are the mostly encountered injury pattern. Denis et al. ${ }^{[1]}$ classified sacral fractures according to the proximity of the fracture line to the sacral foramina. Zone I fractures pass through the alar area, zone 2 fractures through the foramina, and zone 3 fractures through the central canal. Denis zone 3 fractures display the highest risk of neurologic deficit. ${ }^{[2-5]}$ Transversely oriented sacral fractures are also subclassified in zone 3 fractures. Further studies introduced transverse sacral fractures displaying extension through various planes. It was concluded that transverse sacral fractures could not be accommodated into the Denis classification. ${ }^{[6,7]}$

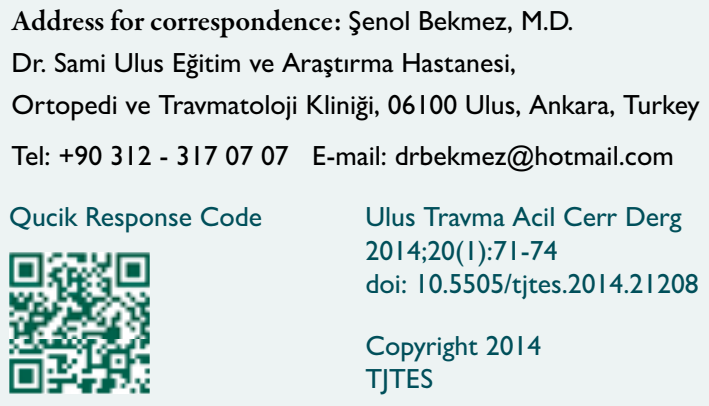

Cauda equina syndrome (CES), described as bladder/bowel dysfunction and SI motor deficit, can accompany displaced transverse sacral fractures via mechanical compression of the sacral nerve roots. Due to imaging difficulties in the sacral area and failure to determine the concomitant neurologic deficit, misdiagnosis is quite common. Limited data, consisting of case series, do not permit assessing any approvable treatment algorithms. ${ }^{[8]}$ In this study, we aimed to report three cases with transverse sacral fractures whose neurological deficits were overlooked initially.

\section{CASE REPORT}

Case I- In October 201I, a 15-year-old male admitted to the emergency department of another hospital after a motor vehicle accident. After the evaluation, bed rest had been recommended with a diagnosis of soft tissue trauma. On the fourth day of the accident, weakness, pain, muscular spasm on lower extremities, and urine retention developed. He admitted to our emergency service with the complaints of pain spreading through the groin, weakness of both legs and urine retention. Decrease in anal tonus and L5 motor weakness on the left side were determined on the physical examination. Radiographic and computed tomography evaluations indicated the displaced high transverse sacral fracture. 
Case 2- In February 2012, a 20-year-old male admitted to our emergency department after a motor vehicle accident. He was mentally confused. It was learned from the patient's relatives that he was a drug addict. Because of his mental disorientation, the neurological examination could not be performed. Displaced high transverse sacral fracture and pubic ramus fracture were detected in the computed tomography scan. Because of patient's lack of cooperation, the neurological examination could not be performed for 48 hours. After 48 hours, the patient became oriented, and perianal saddle type anesthesia and bilateral SI motor weakness were detected.

Case 3- In April 2010, a 21 -year-old male admitted to another hospital after a motor vehicle accident. Sacral fracture and bimalleolar fracture on the left side had been detected. Bed rest had been recommended for his sacral fracture. He admitted to our emergency department with the complaints of increase in pain and weakness on his legs 72 hours after the accident. In the physical examination, perianal saddletype anesthesia, decrease in anal tonus, urinary retention, and bilateral SI motor weakness were detected. Displaced high transverse sacral fracture and left bimalleolar fracture were detected in the radiographic and tomographic evaluations (Figure I).

Between 2010-2012, three patients, with a mean age of 19 (I5-20-2I) years, were admitted and determined to have a displaced high transverse sacral fracture and concomitant CES detected at least 48 hours after the trauma. The mean follow-up of these three patients was 14.6 months (10-1420).

Emergent surgical intervention was performed for the diagnosis of CES. Subsequent to the exploration of the posterior elements between levels L5 and S3, bilateral L5 pedicle screws and iliac screws were placed, preserving the L5 and SI facets. Lumbopelvic fixation was completed with the placement of rods. Schildhauer et al. ${ }^{[9]}$ first described this technique. It is the most stable fixation construct for the posterior pelvic ring according to the biomechanical analyses. ${ }^{[10]}$ Later, SI-S2-
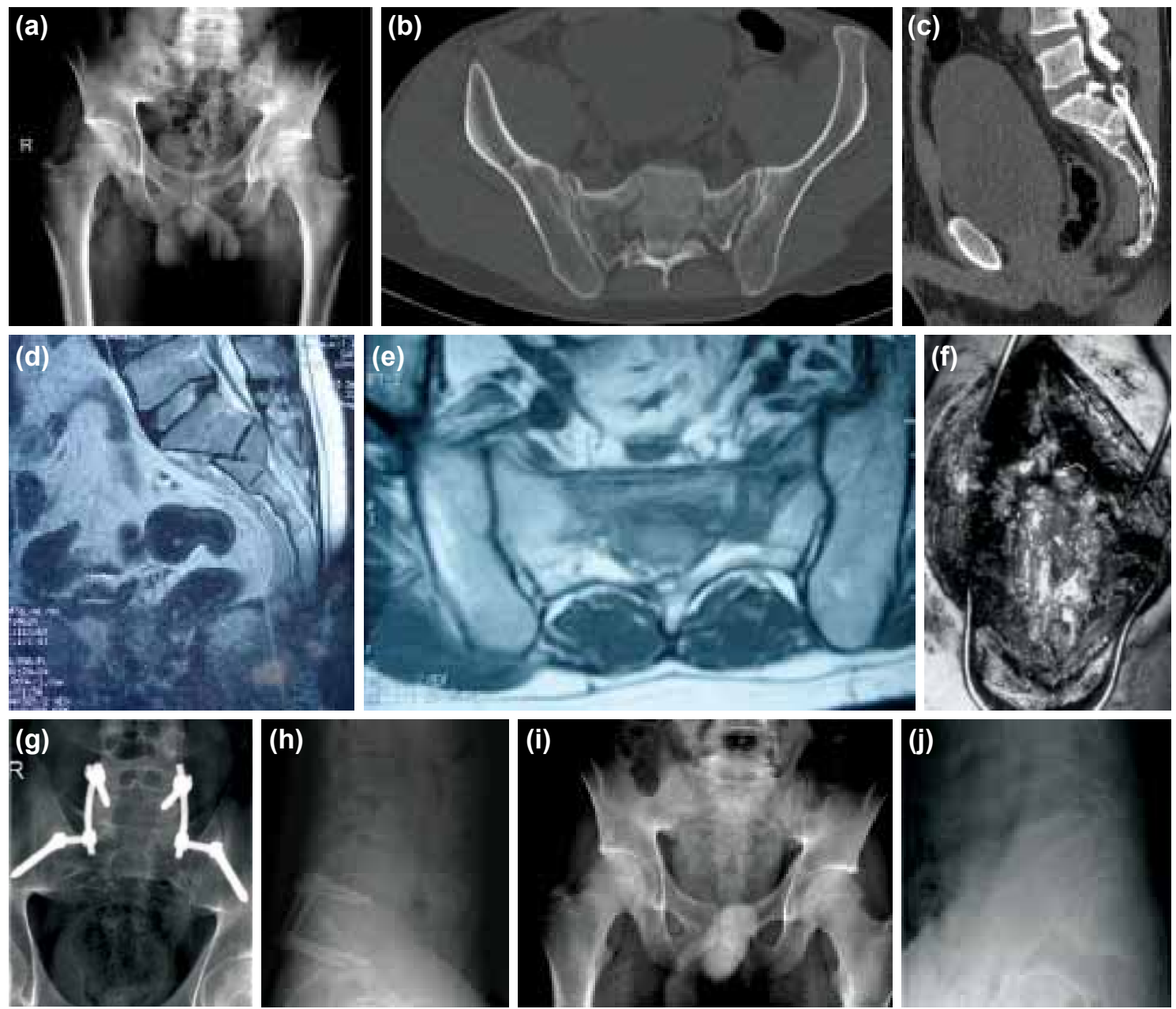

Figure 1. A 21-year-old male with a transverse sacral fracture after a motor vehicle accident. (a) The fracture can be easily overlooked on plain antero-posterior X-ray. (b, c) Axial and sagittal computed tomography scans revealing the displaced fracture fragments encroaching the sacral canal. (d, e) Axial and sagittal MRG scans revealing the caudal compression. (f) Intraoperative view after sacral laminectomy demonstrating the intact sacral nerve roots. (g, h) Postoperative anteroposterior and lateral X-rays. (i, j) Postoperative x-rays taken after implant removal at sixth month. 
S3 laminectomy and decompression of the sacral nerve roots were performed. Nerve roots were edematous and ecchymotic. Bone fragments that encroached on the sacral canal were excised.

In the first 24 hours following the surgery, urinary dysfunction and motor deficits fully recovered immediately in Cases $I$ and 3. Case I reported a decrement in the pain radiating to the adductor area. Oral gabapentin treatment was started for his pain. He was mobilized with full-weight bearing on postoperative day I. Pain complaints completely recovered and implants were removed in the sixth month. In Case 3, open reduction and internal fixation were done for the bimalleolar fracture in the same session. He was mobilized with weight bearing on the opposite side on postoperative day I. The malleolar fracture was united without complication. Implants were removed in the sixth month. The patient was symptom-free at the latest follow-up, except for left deviation of his penis in the course of erection. In Case 2, partial improvement in motor strength was detected in the early postoperative period. Oral gabapentin treatment was started for his complaints of pain in the perianal region. Perianal anesthesia recovered two months after surgery. At the six-month follow-up, his pain had fully recovered and urinary/bladder dysfunction had partially recovered. Full neurologic recovery was detected at the 10-month follow-up.

\section{DISCUSSION}

We aimed to report herein three cases representing our experience with the surgical treatment of displaced transverse sacral fracture with concomitant late-diagnosed CES.

Roy-Camille et al. ${ }^{\left[{ }^{\prime \prime}\right]}$ described transverse sacral fractures as a subtype of Denis zone 3 fractures. Initially, three types were defined, and later, the fourth fracture pattern was included in the classification. ${ }^{[12]}$

There are different characteristics of high and low transverse sacral fracture patterns. High transverse sacral fractures have an $\mathrm{SI}-\mathrm{S} 2$ fracture dislocation pattern with a three-dimensional configuration $\left(\mathrm{H}, \mathrm{U}, \mathrm{T}\right.$ patterns). ${ }^{[13]}$ On the other hand, as low transverse sacral fracture pattern passes caudally through the sacroiliac joint, it is accounted as stable. ${ }^{[14]}$ In our series, all three patients had an unstable fracture pattern, and thus internal fixation was performed.

Transverse sacral fractures can be easily overlooked in the conventional radiographic evaluation. Despite the fact that the fracture can be detected by plain X-rays, coronal and sagittal computed tomography scanning with $1-2 \mathrm{~mm}$ sections is the best means for a detailed evaluation of the posterior pelvic ring. ${ }^{[15]}$

Accompanying neurologic deficit is a clue for the diagnosis of transverse sacral fracture. Denis et al..$^{[1]}$ reported less events of misdiagnosis in the cases with neurologic deficits. Further,
Robles $^{[6]}$ reported a delay in the diagnosis in $37 \%$ of cases. Of the three cases included in this study, delay in diagnosis occurred only in Case I.

Low sacral nerve roots must be examined in a patient with a suspected sacral fracture. Decrease in anal tonus is a valuable examination finding for sacral nerve root damage. ${ }^{[13]}$ Denis et al. ${ }^{[1]}$ reported neurologic deficit in $21 \%$ of cases in their series. The rate increased up to $60 \%$ in the case of a zone 3 pattern. They concluded that transverse fractures present a greater risk of neurologic damage than the vertically oriented fractures. CES, characterized by urinary retention and $L 5$ and/ or SI motor deficit, is the most common neurologic deficit pattern in patients with transverse sacral fractures. ${ }^{[6,16]}$ The neurologic deficit occurring with the mechanisms of angulation and direct compression resolves completely when the mechanical compression disappears. However, neurologic recovery should not be expected with the injury mechanisms of root avulsion or transection. ${ }^{[1]}$ In autopsy series, complete sacral nerve root transection was reported in $35 \%$ of cases.

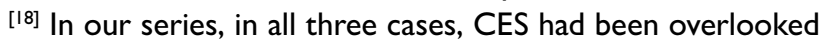
and was diagnosed a minimum of 48 hours after the traumatic event. The intraoperative examination did not reveal any interruptions to the nerve roots.

There is no consensus about the treatment of transverse sacral fractures. Nevertheless, with the increase in understanding about the fracture pattern and the evolution of spinal stabilization systems, surgical treatment has taken over. However, especially in cases occurring due to lowerenergy mechanisms and cases without neurologic deficits, good results have been reported with conservative treatment methods. ${ }^{[19,20]}$ High transverse sacral fractures occurring due to higher-energy mechanisms require internal fixation because of the mechanical instability. ${ }^{\left[{ }^{[2]}\right.}$ Additionally, as a basic rule for spinal surgery, surgical decompression is definitely indicated in cases with neurological deficits and canal encroachment. While neurological recovery is not expected in cases with a complete spinal cord injury after decompression, complete recovery has been reported in the literature in cases of CES. Surgical timing in the case of CES is controversial. The common concept is to consider the first 48 hours as the critical interval. ${ }^{[2-25]}$ However, there are other studies concluding that decompression before or after 48 hours does not influence the neurologic outcome. ${ }^{[26]}$ In a series of 50 patients with CES diagnosed after an average of 12 days, neurologic recovery was evident in all patients who were surgically decompressed. However, the most obvious recovery was reported in the case of emergent surgical decompression. ${ }^{[27]}$ They concluded that loss of anocutaneous reflex is a predictive parameter for bladder/ bowel dysfunction sequelae. ${ }^{[27]}$ According to our own clinical experience, especially in the case of canal encroachment, despite a delay in diagnosis, eliminating the mechanical pressure on the sacral nerve roots immediately results in neurologic recovery. 
Several stabilization methods have been described in addition to surgical decompression. Schildhauer et al. ${ }^{[9]}$ reported the largest series for lumbopelvic fixation. Lumbopelvic fixation is the most reliable stabilization method for the posterior pelvis as determined by biomechanical analyses. Furthermore, this type of fixation permits early full-weight mobilization. ${ }^{[10]}$

In conclusion, despite a delay in diagnosis, we suggest that immediate surgical decompression and stable lumbopelvic fixation have positive effects on the neurologic outcome, early full-weight mobilization and pain control.

\section{Conflict of interest: None declared.}

\section{REFERENCES}

1. Denis F, Davis S, Comfort T. Sacral fractures: an important problem. Retrospective analysis of 236 cases. Clin Orthop Relat Res 1988;227:6781.

2. Gibbons KJ, Soloniuk DS, Razack N. Neurological injury and patterns of sacral fractures. J Neurosurg 1990;72:889-93. CrossRef

3. Santiago P, Fessler RG. Trauma surgery: fractures of the lumbar and sacral spine. In: Benzel EC, editor. Spine surgery: techniques, complication avoidance, and management. 2nd ed. Philadelphia: Elsevier; 2004. p. $563-72$.

4. Wood KB, Denis F. Fractures of the sacrum and coccyx. In: Vaccaro AR, editor. Fractures of cervical thoracic and lumbar spine. New York: Marcel Dekker; 2003. p. 473-88.

5. Wood KB, Denis F. Sacral fractures. In: Vaccaro AR, Betz RR, Zeidman SM, editors. Principles and practice of spine surgery. St. Louis: Mosby Inc.; 2003. p. 487-94.

6. Bonin JG. Sacral fractures and injuries to the cauda equina. J Bone Joint Surg 1945;27:113-27.

7. Nicoll EA. Fractures of the dorso-lumbar spine. J Bone Joint Surg Br 1949;31B:376-94.

8. Sapkas GS, Mavrogenis AF, Papagelopoulos PJ. Transverse sacral fractures with anterior displacement. Eur Spine J 2008;17:342-7. CrossRef

9. Schildhauer TA, Bellabarba C, Nork SE, Barei DP, Routt ML Jr, Chapman JR. Decompression and lumbopelvic fixation for sacral fracture-dislocations with spino-pelvic dissociation. J Orthop Trauma 2006;20:447-57.

10. Schildhauer TA, Josten Ch, Muhr G. Triangular osteosynthesis of vertically unstable sacrum fractures: a new concept allowing early weight-bearing. J Orthop Trauma 2006;20(1 Suppl):44-51.
11. Roy-Camille R, Saillant G, Gagna G, Mazel C. Transverse fracture of the upper sacrum. Suicidal jumper's fracture. Spine (Phila Pa 1976) 1985;10:838-45. CrossRef

12. Strange-Vognsen HH, Lebech A. An unusual type of fracture in the upper sacrum. J Orthop Trauma 1991;5:200-3. CrossRef

13. Watkins RG, Dillin WH. Sacral fractures. In: Cooper PR, editor. Management of posttraumatic spinal instability. Park Ridge, IL: AANS Publications Committee; 1990. p. 163-71.

14. Weaver EN Jr, England GD, Richardson DE. Sacral fracture: case presentation and review. Neurosurgery 1981;9:725-8. CrossRef

15. Templeman D, Goulet J, Duwelius PJ, Olson S, Davidson M. Internal fixation of displaced fractures of the sacrum. Clin Orthop Relat Res 1996;329:180-5. CrossRef

16. Robles LA. Transverse sacral fractures. Spine J 2009;9:60-9. CrossRef

17. Vaccaro AR, Kim DH, Brodke DS, Harris M, Chapman JR, Schildhauer $T$, et al. Diagnosis and management of sacral spine fractures. Instr Course Lect 2004;53:375-85.

18. Huittinen VM. Lumbosacral nerve injury in fracture of the pelvis. A postmortem radiographic and patho-anatomical study. Acta Chir Scand Suppl 1972;429:3-43.

19. Dussa CU, Soni BM. Influence of type of management of transverse sacral fractures on neurological outcome. A case series and review of literature. Spinal Cord 2008;46:590-4. CrossRef

20. Urzúa A, Marré B, Martínez C, Ballesteros V, Ilabaca F, Fleiderman J, et al. Isolated transverse sacral fractures. Spine J 2011;11:1117-20. CrossRef

21. Kostuik JP, Harrington I, Alexander D, Rand W, Evans D. Cauda equina syndrome and lumbar disc herniation.J Bone Joint Surg Am 1986;68:38691.

22. Kennedy JG, Soffe KE, McGrath A, Stephens MM, Walsh MG, McManus F. Predictors of outcome in cauda equina syndrome. Eur Spine J 1999;8:317-22. CrossRef

23. Ahn UM, Ahn NU, Buchowski JM, Garrett ES, Sieber AN, Kostuik JP. Cauda equina syndrome secondary to lumbar disc herniation: a metaanalysis of surgical outcomes. Spine (Phila Pa 1976) 2000;25:1515-22.

24. McCarthy MJ, Aylott CE, Grevitt MP, Hegarty J. Cauda equina syndrome: factors affecting long-term functional and sphincteric outcome. Spine (Phila Pa 1976) 2007;32:207-16. CrossRef

25. Shapiro $S$. Medical realities of cauda equina syndrome secondary to lumbar disc herniation. Spine (Phila Pa 1976) 2000;25:348-52. CrossRef

26. Qureshi A, Sell P. Cauda equina syndrome treated by surgical decompression: the influence of timing on surgical outcome. Eur Spine J 2007;16:2143-51. CrossRef

27. Dhatt S, Tahasildar N, Tripathy SK, Bahadur R, Dhillon M. Outcome of spinal decompression in Cauda Equina syndrome presenting late in developing countries: case series of 50 cases. Eur Spine J 2011;20:2235-9. CrossRef

\section{OLGU SUNUMU - ÖZET}

\section{Transvers sakrum kırıkları ve eşlik eden geç tanı almış kauda ekina sendromu}

\section{Dr. Şenol Bekmez,, ${ }^{1}$ Dr. Gökhan Demirkıran, ${ }^{2}$ Dr. Ömür Cağlar, ${ }^{2}$ Dr. İbrahim Akel, ${ }^{3}$ Dr. Emre Acaroğlu ${ }^{4}$}

${ }^{1}$ Dr. Sami Ulus Kadın Doğum, Çocuk Sağlığı ve Hastalıkları, Eğitim ve Araştırma Hastanesi, Ortopedi ve Travmatoloji Kliniği, Ankara; ${ }^{2}$ Hacettepe Üniversitesi Tıp Fakültesi, Ortopedi ve Travmatoloji Anabilim Dalı, Ankara;

${ }^{3}$ Izmir Kent Hastanesi, Ortopedi ve Travmatoloji Kliniği, İzmir;

${ }^{4}$ Ankara Spine Center, Ortopedi ve Travmatoloji Kliniği, Ankara

Yüksek transvers sakrum kırıkları genç hastalarda yüksek enerjili travma sonrası meydana gelmektedir. Sakrumun radyografik değerlendirmesinde ve sakral düzeydeki nörolojik defisitlerin politravmalı hastalarda değerlendirmesindeki zorluklar nedeniyle bu yaralanmalar gözden kaçabilmektedir. Bu yazıda, üç olgudan oluşan, kauda ekina sendromu tanısı çeşitli nedenlerle geç konulan (en az 48 saat), yüksek enerjili ve kanala bası yapan transvers sakrum kırıklarında cerrahi tedavi sonuçları değerlendirildi. Hastalara sakral laminektomi ve dekompresyon uygulanarak iki taraflı lumbopelvik fiksasyon uygulandı. Her ne kadar kauda ekina sendromu tanısı geç konulsa da, cerrahi dekompresyon ve lumbopelvik fiksasyonun nörolojik fonksiyonlar ve ağrıda düzelme, erken desteksiz mobilizasyon üzerindeki olumlu etkilerini gözlemledik.

Anahtar sözcükler: Atlanmış; ekina; kauda; sakrum; transvers.

Ulus Travma Acil Cerr Derg 20 I4;20(I):71-74 doi: 10.5505/tjtes.20|4.2I 208 